\title{
STUDENTS' GOALS, DEFECTISM, HOPE, POSITIVE AND NEGATIVE EVALUATION OF SCHOOL
}

\author{
Nenad Suzić ${ }^{1 *}$, Drago Branković ${ }^{2}$ \\ *l,2 Faculty of Philosophy Banja Luka
}

*Corresponding Author: -

\begin{abstract}
: -
At a huge sample of 1136 students of the eighth and ninth grade of primary school, as well as of the first and second grade of secondary school, the authors separated four components of target orientation of students by factorization: (1) vulnerability, (2) asociality, (3) affiliative motive and (4) efficiency. They applied the instrument Personality test and job satisfaction of Jim Barett (Barrett, 2009), adapted it to the age and needs of this research ${ }^{3}$, and then they intersected the separated factors with defeatism, hope as well as positive and negative school valuation. Defeatism and hope were measured by DIN test (Defeatism and hope; Suzic, 2017). Positive and negative valuation of school was recorded by DENS test (Suzic, 2009). All students are from Bosnia and Herzegovina of the age from 13 to 16. Half of the sample included Bosniak students and half of it Serbs. The findings show that there are significant differences between Bosniaks and Serbs in terms of majority of observed variables, but that differences can be attributed to the size of the sample and environment rather than nationality. The students that have higher score, achieve better school results in hope test. Negative valuation of the school is connected with defeatism of students. The authors discovered some significant predictors of negative valuation of school. These are: vulnerability, hope, asociality, defeatism, efficency and affiliative motive. These findings are very significant for pedagogic theory and teaching practice because so far we have not had any research data about the relation of comprised variables.
\end{abstract}

Keywords: - defeatism, hope, asociality, affiliative motives, school valuation 


\section{INTRODUCTION}

A more comprehensive view of students' goals implies an analysis of: a) achievements, b) self-assessment and c) social goals (Suzic, 2006). All these categories of goals are not considered here, but specific aspects of social goals and achievement goals. For such observation of goals, Jim Barrett's instrument (Barrett, 2009, p. 131) was used, which is tailored here to the age of the student and calibrated by factorization, ie. reduced to four factors: vulnerability, asociality, affiliative motive and efficiency. In addition, two more tests were applied: DIN-test (Suzic, 2017), PTICA (Adapted with the permission of the author from: Personality test and job satisfaction of Jim Barett (Barrett, 2009).

Defeatism is also known as defensive pessimism. This concept was observed by, inter alia, Andrew Martin with associates (Martin, Marsh, Debus \& Williamson, 2003). They have discovered that students in the future expect poorer success than they have previously achieved in any field (ibidem, 621). Students often see school learning as meaningless. Reasons for this are multiple. Social reality contributes to this because they see that students who were not successful, live better and have more money. Further on, school teaching rewards the reproduction of facts, which is the lowest level in Blum's taxonomy of cognitive learning goals (Bloom, Engelhar, Furst, Hill, \& Krathwohl, 1956). The next reason is that in schools, children are also forced to learn what they will never need in life. Stanley Greenspan says that, as a young man, he was assured that he would not be happy in life if he did not know equations with two unknowns. He is a professor of psychology at George Washington University, and now, at the end of his life, he uses a very complex methodology, based on mathematical patterns, and he has never used equations with two unknowns. He laconically concludes that they were unfair to him in his youth (Greenspan \& Benderly, 1997). There are other important reasons why students cannot see the meaning in school learning. For example, in schools, we teach everyone everything, regardless of the fact that it does not suite some students and that they do not need that knowledge. Furthermore, in schools the teacher assesses, decides, commands, and the like. These and other reasons seriously endanger student motivation and lead them to defeatism.

This paper deals with defeatism of students in relation to school learning and the meaning of life, in relation to the positive and negative evaluation of the school.

Earnest Bloch believes that hope is the most humane feeling (Bloch, 1985). Hope and optimism are not identical terms (Boniwell, 2016). Optimism is a belief that the future will be better, that something positive will happen in the future, and hope implies that a man will do everything he can to achieve the desired. Therefore, the hope implies an active relationship to reality, it implies the idea that a man is a master of his destiny, and optimism implies the attribute or belief that positive things will happen thanks to happiness. Still, it is better to be an optimist than a pessimist. Specifically, optimists are less exposed to stress and depression, optimists endure bad events more easily, optimists plan better, rely on humor, continuously invest in effort, endure obstacles more easily, and do not give up easily (ibidem). Can optimism be learnt? Ilona Bonivel thinks that it can (ibidem), but a person needs to start from a young age. Just as optimism can be developed, it is even more possible to learn hope. Specifically, a person who sees that it is successful in some activity, it invests more hope and effort into this activity, will last longer. Our school system does not support enough student hopes. However, there are experimental schools that support student hope and optimism. For example, in Israel, research has revealed that peer support is a condition of students' well-being (Orkibi, Ronen, \& Assoulin, 2014). In this paper, we measure hope with one subtest of ten questions and one of them is Life is beautiful.

Positive evaluation of the school by the students is hard to expect because the system of education today does not support the basic needs of the child, does not stimulate talents. However, it has been shown that it is possible in schools to measure support to positive behavior (Horner, Todd, Lewis-Palmer, Irvin, Sugai, \& Boland, 2004), but teachers are the key in that support (Filter, Sytsma \& McIntosh, 2016). Regardless of the limitations of the school system, it is possible to influence students, ie, to attract them to evaluate school positively (Lane, Carter, Jenkins, Dwigins, \& Germer, 2015). Research has shown that most students evaluate school negatively (Suzic, 2009). It is interesting that their evaluation of school does not depend on school success (ibidem). This research also brings some optimistic cognitions. Specifically, students who have been trained in learning strategies, value school more (ibidem). This points to the desirable course of action. Namely, if we train students to learn, then they will evaluate the school more positively.

In this paper, we investigate the relations between the goals of education, defeatism, hope and evaluation of school.

\section{Goals of students}

Before they go to school, children get negative attitudes about school, teachers, and school responsibilities. Since starting school till its finishing, or from childhood to adolescence or adulthood, non-school goals of students dominate in relation to school goals of students. However, non-school goals can be transformed into school goals (Suzic, 1999). Specifically, by applying the Goal Adjustment Workshop, I came to the conclusion that the non-school goals of a student can be transformed into school goals (ibidem). When they realize that non-school goals can be more easily achieved by schooling, children start to value the school differently.

Students' goals will be better understood if we break them into categories. This dissolution makes sense only if it will contribute to a better understanding of the whole, Olport believes (Allport, 1961). Here we have tried to meet those Olport's requirements. Students' goals will be better understood in the following categories; 1) goals of achievement, 2) selfassessment, 3) preference in others and 4) social goals (Suzic, 2001). The emphasis here is on social goals. The reason for this is because these goals are very significant for students. Professor Stojan Radenovic, one of the best mathematicians of today, says: "The professor must not be in the center, nor the teacher, the students should be first. When a student realizes this, he becomes happy, unfortunately, we do not respect the main principle of pedagogy - no calling out" (Radenovic, 2016). The teacher dedicates most of the time in the classes to the curriculum, so the curriculum is the subject of teaching, not a student. In addition, the teacher calls out, gives the word, assesses it - he is the God and the supreme judge. In this context of relationships, the student is an object, not a subject of teaching. The greatest success in working 
with students is possible if students turn to one another, rather than to the professor, as the center of decisionmaking and power (Suzic, 2005).

Individuals which show a high score in the tests in the category of social concern, in academic situations try to help others to achieve a high level of achievement (Ford, 1002, McInerney, Roche, McInerney \& Marsh, 1997, Wentzel, 1991). A man is an animal sociale, as Aristotle says. The need to help others is immanent to the human being if they are not egocentric or narcissistic. Narcissism has two sides. Namely, a man cannot love other people if he does not like himself. However, in self-love there is a tiny red line between narcissism and normal selfesteem. People work in the group if they are certain that their contribution is worth something. The research has shown that group members will not make any effort if they estimate that their contribution to group performance is not important and if they notice that they are doing "double" work (Harkins \& Petty, 1982). This, however, does not mean that an individual should attribute the success of a group only to himself. Maximilien Ringelmann in 1913 discovered that individuals prefer to work for themselves than for a group (Ringelmann, 1913). Later on, the authors called this phenomenon the Ringelmann's effect (Abrami, Chambers, Poulsen, De Simone, Apollonia, \& Howden, 1995). This can be used pedagogically by creating teaching models in which the success of an individual will be related to the success of a group.

\section{Defeatism}

Defeatism can be defined as hopelessness, i.e. as a lower level of expectation than realistically possible achievement. Defeatism is not desirable in teaching, but research has shown some of its advantages. First, people with lower expectations than real ones are saved from frustration from failure (Martin, Marsh, \& Debus, 2001; Norem \& Cantor, 1990; Norem \& Illingsworth, 1993). Secondly, defeatism can result in persistence or persisting in case of initial success (Cantor \& Norem, 1989). Thirdly, defeatism may impose an individual to set a lower level of demand, lower level of expectations, and this may result in viable strategies of action (Martin, Marsh, \& Debus, 2001, Showers \& Ruben, 1990). Regardless of these advantages, defeatism is not desirable in teaching. It is much more prosperous to nurture optimism. However, optimism is linked to the future, and our schools are still slaves of the past. Donald Hirsh calls it romance. Namely, he believes that, after the Middle Ages, Europe has achieved its prosperity thanks to Humanism and the Renaissance, and that is why Europe is still turning to this positive past by filling its curricula with programs from that romantic period (Hirsch, 1996). Indeed, children in schools today learn the content that can be found on the internet every second. Children remember such contents to earn the desired mark and then go home to forget it with pleasure.

Defeatism is associated with self-handicapping. Students who do not see the meaning in some activity, easily resort to self-handicapping as a salvation technique to avoid responsibility. High levels of expectations towards students come from parents, peers or teachers. To avoid an obligation that they cannot fulfill, the child often resorts to false excuses: I have $a$ stomachache, I have a toothache, I've forgotten my notebook and so on. Children often use this to protect themselves from demands that are too big (Martin, Marsh, Williamson, \& Debus, 2003). Selfhandicapping can also have specific forms such as hesitation, alcohol or drug consumption, and the like (Berglas \& Jones, 1978; Higgins \& Harris, 1988; Martin, Marsh, \& Debus, 2001). We have investigated defeatism with the instrument of ten items devoted to this phenomenon. One of the questions reads: Nothing can be achieved by learning. In this way, we have taken defeatism of a student and compared it with achievement, hope, students' aspirations and other phenomena.

\section{Hope}

Hope is the opposite feeling of defeatism or hopelessness. Allport believes that every man has at least three images of himself: real I, ideal I and social I (Allport, 1961). The happiness of an individual depends on each of these images. Hope and happiness are directly related. One research has shown that student's happiness is largely dependent on classroom acceptance (Orkibi, Ronen, \& Assoulin, 2014). So this has proven that happiness has also a social dimension. However, it also depends on what a person enjoys, loves and how it feels (Niemiec \& Ryan, 2009; Park, Holloway, Arendtsz, Bempechat, \& Li, 2012). When one eats, sleeps, drinks juice, water or what they want, one feels pleasure. In other words, when one meets the natural needs, one enjoys. Learning is a natural need, but in today's schools, students see learning as an unpleasant activity. Is it possible to reorganize the school so that students feel happy in the school organized in such a way? Research show that this is possible (Orkibi, Ronen, \& Assoulin, 2014).

Hope is always tied to the future. A United Nations document titled "Progress of Nations 2000" (UNESCO, 2000) says that people's happiness in the future will not be recognized by the glory of the shop-windows, the glittering of cities and the power of weapons, but by the established human relations. Thus, social or interpersonal relationships should be seen as a condition of individual happiness. Research has shown that involvement of students in teaching is a prerequisite for their sense of happiness in school (Carter, McGee, Taylor, \& Williams, 2007; van Ryzin, Gravely, \& Roseth, 2009). In order for students in school to be happy, it is necessary, among other things, to fulfill the following conditions: (1) provide self-determined activities, (2) stimulate internal motivated activities, (3) stimulate flow experience, and (4) stimulate target-oriented activities (Orkibi, Ronen, \& Assoulin, 2014). These assumptions are fulfilled if the student is involved in teaching (Skinner, Furrer, Marchand, \& Kindermann, 2008).

In particular, students who learn the techniques and methods of learning will require the teachers to work according to the method that suits them most. Self-determination is not the same as leaving the students to themselves. The teacher can direct the activities of the students pedagogically fulfilling their wishes skillfully.

In the literature available to us, we have not found papers devoted to the question of how much school contribute to the hope of students. However, learning is a natural need, and satisfying the natural needs is accompanied by pleasure. This feeling can be returned to schools if we apply the appropriate Brain Gym techniques because these exercises enable delivery of serotonin, the pleasure hormone and other beneficial hormones (Dennison, 2006). In addition, hope is always 
tied to the future, and schooling does not have a futuristic dimension today. Nevertheless, even existing curricula can be realized futuristically.

\section{Positive evaluation of school}

We cannot expect the students to evaluate positively the school in which the teacher is superior, in which the teacher issues the commands, assigns homework, evaluates it, does not give the students any choice and the like. In these circumstances, we cannot expect students to evaluate the school positively, and this has been shown by research (Suzic, 2009). It was shown that students equally evaluate the school regardless of school success (ibidem). Students who take notes evaluate school positively, as well as those who plan learning, who read efficiently and have good memory (ibidem). This was expected considering the fact that today's schools force memory and reproductive abilities of students.

Numerous components influence whether students will evaluate the school positively or negatively. Students evaluate the school positively if they perceive their attitude towards teachers as correct (Suzic, 2005), if the school gives them possibility of choice (OECD, 2009), if game is linked to learning (Pennington \& Hawley, 1995), if they learn from their peers interactively and cooperatively (Abrami, Chambers, Poulsen, De Simone, Apollonia, \& Howden, 1995), i.e. if they are partners in the teaching and not subordinated.

Nature regulates that a person recalls rather positive than negative emotions. Specifically, if a family loses a dear member by accident, the members of that family do not talk about it for years, and then talk about the deceased person as if the tragedy did not even happen. If in any case the deceased person could make a statement about it, he would ask people to talk about him immediately, and to not wait for three years or more for the trauma to fade away. That is why we should force positive emotions in our schools. The traditional school was based on fear of failure, negative marks, public opinion condemnation, teachers. Positive emotions boost memory (Bohannon, 1998). Nevertheless, even in the traditional school, it is possible to stimulate the students' positive emotions. This is possible: through emotionally designed stories (Heuer \& Reisberg, 1990), through movie clips (Cahill, Prins, Weber, \& McGaugh, 1994), by words, through selected words (LaBar \& Phelps, 1998), through selected images (Bradley, Greenwald, Petry \& Lang, 1992; Christianson \& Fallman, 1990), through the cultivation of flow-experience (Csikszentmihaliy, 1997), through humor (Matijevic, 1994) and in other ways. In traditional teaching, all teachers are trying to master each of these techniques and technologies, but the ranges are limited. All of us teachers are trying to get students interested, to be as better actors, screenwriters or performers, as possible, but modern students want to be involved, to be subjects of teaching. Only when they achieve the role of a subject, a student begins to evaluate teaching positively.

\section{Negative evaluation of school}

Even before they begin to go to school, children are exposed to negative evaluations of school and teaching. For example, the mother says: It's easy with me, you will see when you come to the teacher! The peers satanize the school, school failure is socially treated as an inability, the school is hierarchically arranged because the teacher is superior, the student is subordinate and the like. Nevertheless, research has shown that negative images are easier and faster to memorize than neutral images (Harris \& Pashler, 2005). However, this is true for the relation of neutral and negative images, but we have no research into the effects of memorizing images with negative and positive messages. We can assume that in short-term memory negative images would be better remembered, but also that in a longer period of time, positive images would be better remembered. This is the same as the relationship between good and evil. In the short term, the evil is more efficient, but the good always wins in the long run. This paradigm has seduced many teachers, and they represent the thesis that children will not learn unless we try to scare them.

In a high school, the chemistry professor finished technology and then passed the "pedagogical group of subjects". The pedagogue warned her to apply only one method of teaching, and that such method is not desirable, and it is a drill. She mentioned several comparisons between technology and pedagogy, of course, to the detriment of pedagogy. It was agreed that in another class she would be doing the Blister Copper theme, and in the second, approximately equal classroom, the pedagogue would do the same topic. She did a test of knowledge from that topic. Initially, they recorded both classrooms. She worked in her own way, by drill, and the pedagogue applied teaching leaflets and teaching film. In the pedagogue's class, the students worked independently. The work on this topic lasted for three hours. The same test was applied after processing the topic, finally. The students in her class were better by one point. The teacher warned his colleague that this difference was not statistically significant, but she considered it to be evidence that her method gave better results. After six months, the pedagogue applied that same test in both classrooms, but he took another chemistry professor as the tester, and the test was done when the drill-professor was not in school. The principal approved that colleagues "borrow" geography and biology lessons for this test. Now the students from the pedagogue's classroom were significantly better. The professor was angry that this test was not announced and that she was not in school when it was carried out. The pedagogue told her that he could not tell her in advance for testing because she would keep "drilling" the students from her classroom and that it was also objectively that she is not in school because she would suggest answers during the test. The results of this research were published in one journal (Suzic, 1981). Chemistry Advisor at the Republican Pedagogical Institute, delighted with this text, asked the pedagogue, in the presence of that professor, why her name is not in that paper. The pedagogue replied that he had offered the first author's place to the professor, but she refused. She said: "You did not have to obey me! This example speaks of how particular educators approach their profession.

The school significantly generates negative attitudes of students about fulfilling their school responsibilities and attending school. Students in school find particularly problematic the subjects of natural sciences and mathematics. Research has shown that students have negative attitudes about mathematics and natural sciences, about these classes and teachers (Yager \& McCormack, 1989). This is not the only basis for the negative evaluation of school. In Table 1, Eksi with 
associates gives several parallels by comparing a traditional school with a new school that would be directed to students' needs. Authors tested the STS program (Science, Technology, and Society) in experimental design. It has been shown that the STS program strongly motivates students, that it strengthens students interest and creativity, improves interpersonal relationships between students and teachers, and that students better evaluate scientific knowledge (Akcay, Yager, Iskander \& Turgut, 2010). This research shows that mathematics and natural science are not the only subjects that generate negative attitudes of students about school. There are other factors that we need to keep in mind if we want to reduce the negative attitudes of students about school.

Table 1School learning with the application of STS program compared to traditional teaching

STS program (Program oriented towards the needs of Traditional school program students)

\begin{tabular}{ll}
\hline $\begin{array}{l}\text { Students continually produce ideas. } \\
\text { Students' interest for science is growing from grade } \\
\text { to grade and by application of special courses. }\end{array}$ & $\begin{array}{l}\text { Students have a few original ideas. } \\
\text { Therease of grades. } \\
\text { intudents become more curios in respect of the }\end{array}$ \\
$\begin{array}{l}\text { It seems that science is decreasing curiosity. } \\
\text { Students see their teachers as facilitators/guides. }\end{array}$ & $\begin{array}{l}\text { Students see their teachers as suppliers of } \\
\text { information. }\end{array}$ \\
Students see science as a means of problem solving. & $\begin{array}{l}\text { Students see science as a sum of information which } \\
\text { need to be learnt. }\end{array}$
\end{tabular}

(Akcay, Yager, Iskander \& Turgut, 2010)

The research has shown that taking notes and planning of learning oppositely predetermine the negative attitudes of students about school (Suzic, 2009). In other words, if students take notes and plan their learning, their attitudes about school are less negative than students who do not realize these activities. Thus, planning of learning is the first predictor of positive evaluation of school (ibidem). This research has shown that older students have more negative attitudes about school than younger students (ibidem). According to a survey, if teachers evaluate school negatively, the students will also evaluate school negatively (Ulug, Ozden, \& Eryilmaz, 2011). Therefore, there are a number of factors that predetermine students' attitudes that contribute to their negative evaluation of the school.

In this paper, we search for key predictors that determine whether the students will evaluate the school positively or negatively. In answering this question, we searched through the social goals, defeatism and hopes of students.

\section{Method}

\section{Sample and procedure}

The sample comprised 1136 students, out of which there were 568 Bosniaks from the area of Bihac and 568 Serbs from the area of Banja Luka, out of which 525 male and 611 female students. As it can be seen, the sample is not uniform in terms of sex $\left(\square^{2}=6,51\right.$; significant at the level 0,01). The sample comprised students of two final grades of primary school and two initial grades of secondary school, therefore, the age between 13 and 17. All students filled in a set of three instruments: adapted PTICA-test (Barret, 2009), DIN-test (Suzic, 2009). Testator (researcher) was reading the questions, and the students encircled one out of ten numbers, ie. $1=$ I disagree completely, and $10=$ I agree completely for the tests PTICA and DIN, and for DENStest the students had the Likert scale from $0=I$ do not agree to $4=I$ agree. There are several advantages of reading the items: problems were avoided in the speed of reading of particular students, all questions are emphasized equally, if something is not clear the student could raise his hand and ask the testator, rhythm of answering is the same for all students - the students answer honestly and spontaneously, they do not have time for calculations. Data from the filledin questionnaires were entered in the computer and by means of statistic SPSS 20 (Statistica for Windows) were processed and variables were methodologically intersected.

\section{Measures}

We measured determination of students to evaluate the school positively or negatively by DENS test, and we measured the predictors of this determination only by PTICA and DIN-test.

DENS-test (Suzic, 2009) has 20 items, particles or statements answered by the students by encircling one out of five numbers meaning: 0) = I disagree, 1) I partially agree, 2) = I moderately agree, 3) = I mostly agree and 4) = I completely agree. Ten questions relate to positive school valuation, and their internal consistency is respectable $(\alpha=0,87)$, and ten questions relate to negative school valuation $(\alpha=0,86)$. One of the items for negative school valuation is: Teachers in this school do not even think about to make lessons interesting. Example of items for positive valuation of school is: Most of lessons resembles a game so we do not feel it is a teaching.

PTICA-test (Barrett, 2009) has 40 items in original version, and after factorization and adaptation for this research, it has 22 items. By factorization, four factors were separated: (1) vulnerability -5 items $(\alpha=0,64),(2)$ asociality -7 items $(\alpha$ $=0,58)$, (3) affiliative motive -6 items $(\alpha=0,62)$ and (4) efficiency -4 items $(\alpha=0,55)$. Example of vulnerability item is: I get worried easily. Statements are answered with: 1) I do not agree at all to $10=$ I agree completely. Example of asociality item is: Practically, it is not important for me to have friends. One of the items for affiliative motive is: My favourite activity is to entertain friends, and for efficiency, one of the items is: I allocate necessary time to prepare for something that could be heavy. This instrument is intended to measure aspiration of people, and we adapted it here to the adolescence age and reduced by factorization to four target orientations. 
DIN-test (Suzic, 2017) has 29 items out of which 15 items dedicated to defeatism $(\alpha=0,76)$, and 14 to hope $(\alpha=0,72)$. Instrument is filled in so that the students encircle one out of ten items of the Likert scale, ie. $1=$ I do not agree at all, and $10=$ I agree completely. One of the fifteen questions for measuring of defeatism is: There are more bad than good people in this world and everyone is trying to trick you. One of the fourteen questions for measuring of hope is:

I am always followed by luck.

\section{Findings}

The basic hypothesis or research question in this paper is whether we can detect predictors of negative and positive valuation of school. In order to answer that question, we made correlation intersection of each with each variable (Table 2), and then we put significant links into a multiple regression model (Bryman \& Cramer, 2001), to follow Stepwise method (Table 3 and Table 4) and separate key predictors of positive and negative school valuation. Further on, we were interested in whether ethnic differences exist among students on the basis of vulnerability, asociality, affiliative motive, efficiency, defeatism and hope (Table 5)

\section{Negative valuation of school}

It has been shown that the negative valuation of the school has more significant correlations with variables related to student's target orientation, defeatism and hope than positive school valuation (Table 2). It is interesting to note that a number of students valuates school both negatively and positively $(r=0.38$; significantly at the level 0.01 , Table 2$)$. We could expect this because schools today bring a series of positive but also negative outcomes to children. For example, Andrew Martin with collaborators found that schools do not only make good impacts on children (Martin, Marsh, Williamson, \& Debus, 2003). They found that schools generate fear of failure, self-handicapping, defensive pessimism, and avoidance of work (ibidem).

Table 2 Pearson correlation of all variables

\begin{tabular}{|c|c|c|c|c|c|c|c|c|}
\hline Variable & 1 & 2 & 3 & 4 & 5 & 6 & 7 & 8 \\
\hline 1) Vulnerability & & & & & & & & \\
\hline 2) Asociality & $0,05^{*}$ & & & & & & & \\
\hline 3) Affiliative motive & $0,04 * *$ & - & & & & & & \\
\hline & & $0,07 * *$ & & & & & & \\
\hline 4) Efficiency & $0,30 * *$ & $0,08^{* *}$ & $0,29 * *$ & & & & & \\
\hline 5) Defeatism & $0,13 * *$ & $0,32 * *$ & $0,10 * *$ & - & & & & \\
\hline 6) Hope & $0,15^{* *}$ & $-0,05^{*}$ & $0,43 * *$ & $\begin{array}{c}0,06 * \\
0,37 * \\
*\end{array}$ & $\overline{0}, 15^{* *}$ & & & \\
\hline $\begin{array}{l}\text { 7) Negative school } \\
\text { valuation }\end{array}$ & $0,32 * *$ & $0,19 * *$ & $0,28 * *$ & $\begin{array}{c}0,28 * \\
*\end{array}$ & $0,18 * *$ & $0,26 * *$ & & \\
\hline $\begin{array}{l}\text { 8) Positive school } \\
\text { valuation }\end{array}$ & $0,22 * *$ & 0,03 & $0,31 * *$ & $\begin{array}{c}0,30 * \\
*\end{array}$ & 0,02 & $0,38 * *$ & $0,38 * *$ & - \\
\hline $\mathrm{M}$ & 6,21 & 3,38 & 7,35 & 8,17 & 4,55 & 7,23 & 5,76 & 7,85 \\
\hline SD & 1,88 & 1,44 & 1,54 & 1,45 & 1,42 & 1,23 & 1,89 & 1,24 \\
\hline
\end{tabular}

Note: $*$ = significant at .05 level; $* *=$ significant at .01 level.

As predictors of negative school valuation, we set six variables: vulnerability, asociality, affiliative motive, efficiency, defeatism and hope (Table 3). By multiple regression, six models were generated which explained from 10 to $22 \%$ of variance (Table 3 ). 
Table 3 Predictors of negative school valuation

\begin{tabular}{lrrrrrr}
\hline Model & $B$ & $S E$ & $\beta$ & $t$ & $p$ & $\mathrm{R}^{2}$ \\
\hline 1. Constant & 4.52 & .12 & & 39.09 & .000 & .10 \\
Vulnerability & .20 & .02 & .317 & 11.23 & .000 & \\
\hline 2. Constant & 3.13 & .21 & & 15.12 & .000 & .15 \\
Vulnerability & .18 & .02 & .284 & 10.25 & .000 & \\
Hope & .21 & .03 & .234 & 8.57 & .000 & \\
\hline 3. Constant & 2.59 & .22 & & 15.12 & .000 & .18 \\
Vulnerability & .18 & .02 & .284 & 10.25 & .000 & \\
Hope & .21 & .03 & .222 & 8.01 & .000 & \\
Asociality & .15 & .02 & .182 & 6.75 & .000 & \\
\hline 4. Constant & 2.12 & .24 & & 8.92 & .000 & .20 \\
Vulnerability & .16 & .02 & .254 & 9.29 & .000 & \\
Hope & .24 & .03 & .254 & 9.29 & .000 & \\
Asociality & .12 & .02 & .141 & 5.01 & .000 & \\
Defeatism & .11 & .02 & .137 & 4.77 & .000 & \\
\hline 5. Constant & 1.17 & .26 & & 6.47 & .000 & .21 \\
Vulnerability & 1.14 & .02 & .219 & 7.77 & .000 & \\
Hope & .20 & .03 & .212 & 7.37 & .000 & \\
Asociality & .10 & .02 & .127 & 4.51 & .000 & \\
Defeatism & .12 & .02 & .147 & 5.16 & .000 & \\
Efficiency & .11 & .02 & .131 & 4.39 & .000 & \\
\hline 6. Constant & 1.16 & .26 & & 6.00 & .000 & .22 \\
Vulnerability & .12 & .02 & .196 & 6.70 & .000 & \\
Hope & .17 & .03 & .176 & 5.72 & .000 & \\
Asociality & .11 & .02 & .138 & 4.88 & .000 & \\
Defeatism & .11 & .02 & .133 & 4.59 & .000 & \\
Efficiency & .10 & .02 & .123 & 4.11 & .000 & \\
Affiliative motive & .07 & .02 & .090 & 2.86 & 0.004 & \\
\hline
\end{tabular}

The sixth model shows symptomatically what affects negatively the student valuation of the school. Today, among the first-grade pupils in every classroom, there are several children that no one has ever pulled by their ear. Even when someone rises his voice at them, their tears are sparkling in their eyes. For traditional school, these are vulnerable or hypersensitive children. Our teachers are not trained to work with such children. In addition, vulnerable students are not provided any protection by school. The second predictor in the sixth model of multiple regression is hope. What kind of hope can a student have who learns first to get a mark, who learns to satisfy teachers and parents first? Our schools do not implement curricula futurologically (Suzic, 2012). How can one hope if his work is not related to future? Hope is related to happiness, with a sense of satisfaction and enjoyment of what a person is doing (Niemiec \& Ryan, 2009, Park, Holloway, Arendtsz, Bempechat, \& Li, 2012). Let us ask ourselves to what extent children feel the joy of cognition, how much they learn with pleasure, if we know that they use phrases for learning such as cramming and swotting and the like? Asociality is the next predictor of negative school valuation. Why? Schools encourage competition rather than competence. Specifically, the teacher asks, and more students respond. The one who answers correctly wins the points from the teacher, and these others put their hands up in vain. In these circumstances, some students will not even put up their hand, as they experience that as conforming. By nurturing competition, a hierarchically shaped traditional school does not support student socialization. It nurtures more individualism and conformism.

The next predictor of students' negative attitudes about school is defeatism. The adolescent sees his peer, the son of the cafe owner, driving an expensive car despite being a poor student. He concludes that it is meaningless to learn because he cannot accomplish with his diploma what others can without a diploma. By adopting defeatism or a hopelessness, a child can easily resort to a strategy of self-handicapping, and this strategy has more unwanted forms (Berglas \& Jones, 1978; Higgins \& Harris, 1988; Martin, Marsh, \& Debus, 2001). It could be said that schools stimulate defeatism rather than hope. Schools are today a place for formal commitment of children, a place to delay meeting of children and parents with reality. Specifically, the parent says to the child: You just finish school, and then we will somehow get the job through a connection. When a student graduates, he meets the reality, confronting the truth. The children feel this and they do not see the school as a place where they will adopt optimism.

Efficiency is the next predictor of negative school valuation. Indeed, it is impossible to expect that students see the school as a support to their effeciency when neither they nor their teachers know for what this knowledge will be used in the future. Students learn to go through a labyrinth called school, and teachers work according to curricula, and it is important that they know the subject better than textbooks. Combs said scenically that the school is a corral for putting people in one place, and only teachers know the way out (Combs, 1959).

School is the place where children gather, where they realize a significant aspect of their socialization. The need children for peer-to-peer socialization is most directly achieved in school. However, affiliative motive in our research has shown to be a negative predictor of school valuation. Why is that so? With its hierarchical structure and established competitive relationships, the school is more supportive of individualism than of the affiliative motive. However, cooperative and interactive learning supported affiliative motive of students (Johnson \& Johnson, 1987). Here we can expect that one number of students see the school as a place for socializing with peers, and it is clear that there is a significant number of students who search out of school the peers having similar views and goals. 


\section{Positive school valuation}

It is not surprising that there are less positive than negative predictors according to which the students value the school. Table 2 gives us a base to put four predictors of positive school valuation in the model of multiple regression (Table 4).

Table 4 Predictors of negative school valuation

\begin{tabular}{lrrrrrr}
\hline Model & $B$ & $S E$ & $\beta$ & \multicolumn{1}{c}{$t$} & $P$ & $\mathrm{R}^{2}$ \\
\hline 1. Constant & 4.14 & .20 & & 20.72 & .000 & .14 \\
Hope & .38 & .03 & .379 & 13.76 & .000 & \\
\hline 2. Constant & 3.33 & .24 & & 14.21 & .000 & .17 \\
Hope & .31 & .03 & .311 & 10.70 & .000 & \\
Efficiency & .16 & .03 & .184 & 6.31 & .000 & \\
\hline 3. Constant & 2.98 & .24 & & 12.38 & .000 & .19 \\
Hope & .25 & .03 & .251 & 8.12 & .000 & \\
Efficiency & .14 & .03 & .160 & 5.50 & .000 & \\
Affiliative motive & .13 & .02 & .160 & 5.34 & .000 & \\
\hline 4. Constant & 2.88 & .24 & & 11.90 & .000 & .20 \\
Hope & .26 & .03 & .295 & 8.38 & .000 & \\
Efficiency & .12 & .03 & .137 & 4.59 & .000 & \\
Affiliative motive & .10 & .03 & .130 & 4.14 & .000 & \\
Vulnerability & .06 & .02 & .095 & 3.25 & .001 & \\
\hline
\end{tabular}

Particularly interesting is the fourth prediction model that shows that hope, efficiency, affiliative motive, and vulnerability predict positive school valuation, and these same variables predict the negative valuation of the school. How can be this explained? Simply, a number of students see school as an institution that stimulates hope, efficiency, affiliative motive, and protects the vulnerable, while the other, slightly larger number sees the opposite. Here we would have a benefit from new research to find out what the emotions of both groups of students are like, whether conformism is more pronounced in those who positively value the school than those who value this institution negatively, which of these students feel happy at school and the like.

Here we are able to see the success of students who value the school positively, compared to those who value the school negatively or those who have a moderate attitude (Table 5). We calculated the arithmetic means and the standard deviations for the positive and negative valuation of the school. Then we separated all those above and below a standard deviation from the arithmetic mean and got three groups: (1) those who valuate the school above average (+1 SD of M, (2) those who value the school averagely ( \pm 1 SD from M) and (3) those who valuate the school positively below average $(-1 \mathrm{SD}$ of M). We ranked these categories by school success (Table 4), and we used ANOVA as the most appropriate statistical procedure.

Findings in Table 4 show that there is no statistically significant difference with respect to school valuation among students. One number of students (110 or 9,68\%) did not answer about their opinion about school - they gave all maximal or all minimal marks for both positive and negative valuation. These are the students that did not want to present their opinion about school although the testator pointed out that the names will be protected, ie. confidential. It would be best to reject this part of sample in final consideration of the research findings. It is interesting that greater number of students valuates the school extremely negatively (116 or $10,21 \%)$ than extremely positively (98 or 8,63\%). However, average of above average positive valuations $(M=4,23 ; S D=0,87$; Table 4$)$ is bigger than the average of negative valuations of school $(M=4,01 ; S D=1,12$; Table 4$)$. Here we cannot say what is in essence of these valuation, but this would be an interesting phenomenon for new research.

Table 4: Valuation of school considering the school results and age

\begin{tabular}{|c|c|c|c|c|c|c|c|c|c|}
\hline \multirow{2}{*}{$\begin{array}{l}\text { Vari- } \\
\text { able }\end{array}$} & \multirow{2}{*}{$\begin{array}{l}\text { Valuation } \\
\text { of } \\
\text { school }\end{array}$} & \multirow[t]{2}{*}{$N$} & \multirow[t]{2}{*}{$M$} & \multirow[t]{2}{*}{$S D$} & \multirow[t]{2}{*}{$S E$} & \multicolumn{2}{|c|}{$\begin{array}{c}\text { Interval of } \\
\text { reliability }(95 \%)\end{array}$} & \multirow[t]{2}{*}{$F$} & \multirow[t]{2}{*}{$p$} \\
\hline & & & & & & Lowest & Highest & & \\
\hline \multirow{5}{*}{ 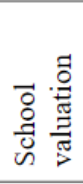 } & Neutral & 110 & 4.13 & .86 & .08 & 3.97 & 4.29 & & \\
\hline & Negative & 116 & 4.01 & 1.12 & .10 & 3.80 & 4.21 & & \\
\hline & Average & 812 & 4.08 & .90 & .32 & 4.02 & 4.15 & & \\
\hline & Positive & 98 & 4.23 & .87 & .88 & 4.06 & 4.41 & & \\
\hline & Total & 1136 & 4.09 & .92 & .03 & 4.04 & 4.15 & 1.18 & .315 \\
\hline \multirow{5}{*}{$\stackrel{8}{4}$} & Neutral & 110 & $\begin{array}{c}14.9 \\
5\end{array}$ & .97 & .09 & 14.77 & 15.14 & & \\
\hline & Negative & 116 & $\begin{array}{c}14.7 \\
3\end{array}$ & 1.12 & .10 & 14.53 & 14.94 & & \\
\hline & Average & 812 & $\begin{array}{c}15.0 \\
3\end{array}$ & .97 & .03 & 14.96 & 15.10 & & \\
\hline & Positive & 98 & $\begin{array}{c}15.0 \\
4\end{array}$ & 1.07 & .11 & 14.83 & 15.26 & & \\
\hline & Total & 1136 & $\begin{array}{c}14.9 \\
9\end{array}$ & 1.00 & .03 & 14.93 & 15.05 & 3.14 & .025 \\
\hline
\end{tabular}


The data in Table 4 show that along with the increase of age, there is increase of positive valuation of school. The highest score at positive school valuation was accomplished by the oldest students, older than 15 years $(M=15,04 ; S D=1,07$; Table 4). This finding is contrary to the results of one previous research (Suzic, 2009). It is probably about difference that stems from various samples. Here new research would be desirable on a huge sample and if possible, longitudinally.

It is symptomatic that 1028 students $(90,49 \%)$ values school neutrally, negatively or averagely. The school should be a place of joy of cognition (Ajdacic, 1998), a place of correct relations among the people (Suzic, 2005), the institution that provides the students possibility to choice (OECD, 2009), a place where the game is connected with learning (Pennington \& Hawley, 1995), the place where the students learn from one another (Abrami, Chambers, Poulsen, De Simone, d'Apollonia, \& Howden, 1995), a place where they train their brain muscles, a place for Brain-gym (Dennison, 2006), a place of learning for future and for learning how to learn (Suzic, 2012). If school would be organized according to these requests, we are sure that the students would value it positively.

The sample makes us to explore another research question. Whether Serbs and Bosniaks differ according to comprised variables? We asked for the answers by calculation of $t$-values. This is the most adequate measure for evaluation of difference of arithmetic means (Graph 1). With respect to vulnerability, there is a difference between Serbs and Bosniaks $(t=-4,08$; significant at level 0,001), which shows that the Bosniak students are more vulnerable than the students Serbs. Asociality is expressed in students of Bosniak nationality ( $t=-6,36$; significant at level 0,001$)$. In terms of affiliative motive, there is no difference between Bosniaks and Serbs $(t=-1,74$; not statistically significant. Efficiency was registered in Bosniak students at the higher level then the Serb ones $(t=-5,84$; significant at level 0,001). Defeatism is the variable according to which the students of Serbian and Bosniak nationality do not differ statistically significantly $(t=1,64$; not statistically significant). The students of Bosniak nationality show higher level of hope than the students of Serbian nationality $(t=-4,53$; significant at level 0,001). The level of negative valuation of school of Bosniak students is higher than the students of Serbian nationality $(t=-5,28$; significant at level 0,001), but the same counts for the level of positive valuation of school $(t=-7,23$; significant at level 0,001). Although statistically significant difference are not recorded, the Graph 1 shows that the students of Bosniak and Serbian nationality are approximately at the same levels of answering
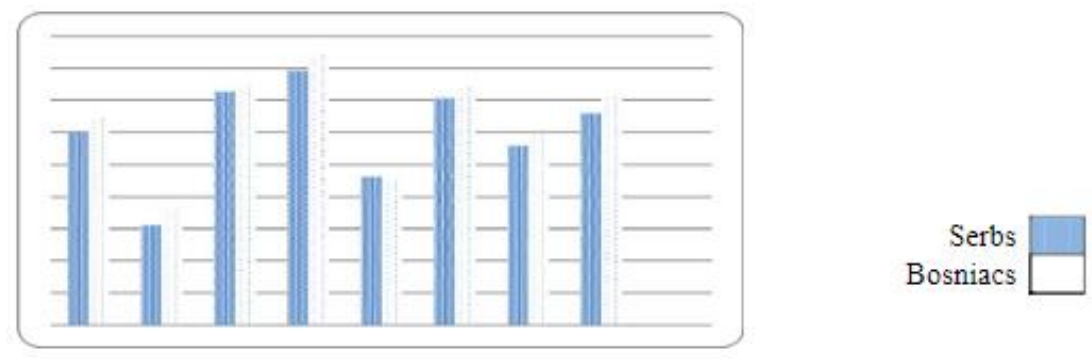

Note: 1 = Vulnerability; 2 = Asociality; 3 = Affiliative motive $; 4=$ Efficiency $; 5$ = Defeatism; $6=$ Hope; $7=$ Negative valuation of school; $8=$ Positive valuation of school

Graph 1. Difference between Bosniaks and Serbs per all observed variables all comprised variables. Differences found should be attributed rather to sample and environment from which the students come than to nationality.

\section{Conclusion}

Our schools carry out curricula, and the students are there to serve as a measure of the effectiveness of this realization. It is understandable that students do not see such a school as their institution. It is declaratively advocated that education should be matched to the needs of students, and in the classrooms the main concern of the teacher is the realization of the curriculum. In this way, the subject of teaching is not a student, but the subject matter. However, this research has shown that a significant number of students experience school ambivalently, both good and bad. Interestingly, only about $10 \%$ of students see the school positively, and the other $90 \%$ evaluate school negatively, neutrally or ambiguously.

Classroom work in classes, ie. curricular and extracurricular work can be transformed to the desired direction, but this does not happen in practice. Why? This is a serious job for which teachers should be trained, and that costs! Here, education is still treated as spending. In this research, we have pointed out in what direction modernization of education should be pursued: to develop cooperative and interactive learning, to give students the option of choice, to match play and learning, to learn from each other, to be in the zone of advanced development, to embed Brain-gym exercises in all the lessons, to realize the curricula futurologically, simply, to learn how to learn. Special training for teachers is required for each of these activities. Our teachers are extremely valuable and their training is not difficult to organize, but everything stops on the issue of material, ie. financial possibilities.

Here, we did not resist the challenge to compare Bosniak and Serb students. It appeared that Bosniak students showed a statistically significant higher level of vulnerability, asociality, but also affiliative motive. Bosniak students estimate that they have higher levels of efficiency, that their school gives them more hope, but have a higher level of positive and negative school valuation than Serbs. The calculated $t$-values at all these variables are significant, but this significance can be attributed to the sample size because graphical presentation of these variables (Graph 1) shows that they are much more matched than they differ.

By exploring the phenomenon of target orientation, defeatism and hope in the context of school valuation, we came up with ideas for new research. We hope these ideas will inspire authors to new research needed by pedagogical theory and teaching practice, 
The limit of this study is that research is transversal rather than longitudinal. The second limit is a pattern. It would be good to check these findings on a representative sample for the entire $\mathrm{BiH}$. The third limit is in the instrumentation. We comprised some important variables, but there are a number of other significant variables that would be desirable to engage in new research with a more complex instrumentation.

\section{Reference}

[1].Abrami, P. C., Chambers, B., Poulsen, C., De Simone, C., d'Apollonia, S., \& Howden, J. (1995). Classroom connections: Understanding and using cooperative learning. New York, NY: Hartcourt Brace.

[2].Ajdačić, V. (1998). Nauka kao bajka [Science as a fairy tale]. Beograd, Srbija: Zlatna knjiga.

[3].Akcay, H., Yager, E. R., Iskander, S. M., \& Turgut, H. (2010). Change in student beliefs about attitudes toward science in grades 6-9. Asia-Pacific Forum on Science Learning and Teaching, 11(1), 1-9.

[4].Allport, G. W. (1961). Pattern and growth in personality. New York, NY: Holt, Rinehart and Winston.

[5].Barrett, J. (2009). Aptitude, personality and motivation tests: Analyse your talents and personality, and plan your career. London, UK: Kogan.

[6].Berglas, S., \& Jones, E. E. (1978). Drug choice as a self-handicapping strategy in response to noncontingent success. Journal of Personality and Social Psychology, 36, 405-417.

[7].Bloom, B. S., Engelhar,t M. D., Furst, E. J., Hill, W. H., \& Krathwohl, D. R. (1956). Taxonomy of Educational Objectives, Handbook I: The Cognitive Domain. New York, NY: David McKay Co Inc.

[8].Bohannon, J. N., III (1988). Flashbulb memories for the space shuttle disaster: A tale of two theories. Cognition, 29, 179-196.

[9].Boniwell, I. (2016). Optimism and hope. Positive Psychology. http://positivepsychology.org.uk/optimism-and-hope/. Read: 08.12.2016.

[10]. Bradley, M. M., Greenwald, M. K., Petry, M. C., \& Lang, P. J. (1992). Remembering pictures: Pleasure and arousal in memory. Journal of Experimental Psychology: Learning, Memory, \& Cognition, 18, 379-390.

[11]. Bryman, A., \& Cramer, D. (2001). Quantitative data analysis with SPSS release 10 for Windows: A guide for social scientists. New York: Routledge.

[12]. Cahill, L., Prins, B., Weber, M., \& McGaugh, J. L. (1994). Beta-adrenergic activation and memory for emotional events. Nature, 20, 702-704.

[13]. Cantor, N., \& Norem, J. K. (1989). Defensive pessimism and stress and coping. Social Cognition, 7, $92-112$.

[14]. Carter, M., McGee, R., Taylor, B., \& Williams, S. (2007). Health outcomes in adolescence: Associations with family, friends and school engagement. Journal of Adolescence, 30, 51-62. doi: 10.1016/j.adolescence.2005.04.002

[15]. Christianson, S. A., \& Fallman, L. (1990). The role of age on reactivity and memory for emotional pictures. Scandinavian Journal of Psychology, 31, 291-301.

[16]. Combs, A. W. (1959). Personality: Theory and its implications for curriculum development. Washington, DC: National Education Association.

[17]. Csikszentmihaliy, M. (1997). Finding flow: The psychology of engagement with everyday life. New York, NY: Basic Books.

[18]. Dennison, P. E. (2006). Brain gym and me: Reclaiming the pleasure of learning. Ventura, CA: Paul E. Dennison.

[19]. Ernst, B. (1985). Werkausgabe: Band 5: Das Prinzip Hoffnung. Frankfurt am Main, DDR: Suhrkamp.

[20]. Filter, K. J., Sytsma, M. R., \& McIntosh, K. (2016). A brief measure of staff commitment to implement school-wide positive behavioral interventions and supports. Assessment for Effective Intervention, 42(1), 18-31. doi: $10.1177 / 1534508416642212$

[21]. Ford, M, E. (1992). Motivating humans: Goals, emotions, and personal agency. Newbury, CA: Sage.

[22]. Greenspan, S. I., \& Benderly, B. L. (1997). The growth of the mind and the endangered origins of intelligence. Reading, Massachusetts: Perseus Books.

[23]. Harkins, S. G., \& Petty, R. E. (1982). Effect of task difficulty and task uniqueness on social loafing. Jornal of Social Psychology, 43(6), 1214-1229. doi: 10.1037/00223514.43.6.1214

[24]. Harris, C. R., \& Pashler, H. (2005). Enhanced memory for negatively emotionally charged pictures without selective rumination. Emotion, 5(2), 191-199. doi: 10.1037/15283542.5.2.191

[25]. Heuer, F., \& Reisberg, D. (1990). Vivid memories of emotional events: The accuracy of remembered minutiae. Memory \& Cognition, 18, 496-506.

[26]. Higgins, R. L., \& Harris, R. N. (1988). Strategic 'alcohol' use: Drinking to self-handicap. Journal of Social and Clinical Psychology, 6, 191-202.

[27]. Hirsch, Jr., E. D. (1996). The schools we need and why we don't have them. New York: Doubleday.

[28]. Horner, R. H., Todd, A. W., Lewis-Palmer, T., Irvin, L. K., Sugai, K., \& Boland, L. B. (2004). The school-wide evaluation tool (SET): A research instrument for assessing school-wide positive behavior support. Journal of Positive Behavior Interventions, 6(1), 3-12. doi: 1177/10983007040060010201

[29]. Johnson, D. W., \& Johnson, R. T. (1987). Learning together and alone: Cooperation, competition, and individualization. 2nd ed. Englewood Cliffs, NJ: Prentice-Hall.

[30]. LaBar, K. S., \& Phelps, E. A. (1998). Arousal-mediated memory consolidation: Role of the medial temporal lobe in humans. Psychological Science, 9, 490-493.

[31]. Lane, K. L., Carter, E. W., Jenkins, A., Dwigins, L., \& Germer, K. (2015). Supporting comprehensive, integrated tree-tiered models of prevention in schools: Administrators' perspectives. Journal of Positive Behavior Interventions, 17(4), 209-222. doi: 10.1177/1098300715578916 
[32]. Martin, A. J., Marsh, H. W., \& Debus, R. L. (2001). A quadripolar need achievement representation of selfhandicapping and defensive pessimism. American Educational Research Journal, 38(3), 583-610.

[33]. Martin, A. J., Marsh, H. W., Williamson, A., \& Debus, R. L. (2003). Self-handicapping, defensive pessimism, and goal orientation: A qualitative study of university students. Journal of Educational Psychplogy, 95(3), 617-628. doi: 10.1037/0022-0663.95.3.617

[34]. Matijević, M. (1994). Humor u nastavi:Pedagoška i metodička analiza [Humor in teaching: Pedagogical and methodical analysis]. Zagreb, Hrvatska: UNA-MTV.

[35]. McInerney, D. M., Roche, L., McInerney, V., \& Marsh, H. W. /1997). Cultural perspectives and school motivation: The relevance and application of goal theory. American Educational Research Journal, 34(1), 207-236.

[36]. Norem, J. K., \& Cantor, N. (1990). Fefensive pessimism: Harnessing anxiety as motivation. Journal of Personality and Social Psychology, 51, 1208-1217.

[37]. Norem, J. K., \& Illingsworth, K. S. S. (1993). Strategy-dependent effects of reflecting on self and task: Some implications of optimism and defensive pessimism. Journal of Personality and Social Psychology, 65, 822-835.

[38]. OECD (2009). Creating effective teaching and learning environments: First results from TALIS: Teaching and learning survay. www.sourceoecd.org/9789264056053. Read: 25.12.2016.

[39]. Orkibi, H., Ronen, T., \& Assoulin, N. (2014). The subjective well-being of Israeli adolescents attending specialized school classes. Journal of Educational Psychology, 106(2). 215-256. doi: 10.1037a/0035428

[40]. Pennington, J., \& Hawley, P. (1995). Use of educational gaming to enhance theory learning. JNY State Nurses Association. PubMed, 26(3), 4-6.

[41]. Раденовић, С. (2016). Најутицајнији српски математичар: Министра не занима шта мислим (аудио) [Most influential Serbian mathematician: Minister is not interested in what I mean (audio)]. https://rs.sputniknews.com. 14.12.2016.

[42]. Ringelmann, M. (1913). Recherches sur les moteurs animés: Travail de l'homme [Research on animate sources of power: The work of man], Annales de l'Institut National Agronomique, 2nd $\quad$ series, $\quad$ vol. 12 (pp. $1-$ 40). Available on-line (in French) at: http://gallica.bnf.fr/ark:/12148/bpt6k54409695.image.f14.langEN

[43]. Showers, C., \& Ruben, C. (1990). Distinguishing defensive pessimism from depression: Negative expectations and positive coping mechanisms. Cognitive Therapy and Research, 14, 385-399.

[44]. Skinner, E. A., Furrer, C., Marchand, G., \& Kindermann, T. (2008). Engagement and disaffection in the classroom: Part od a larger motivational dynamic? Journal of Educational Psychology, 100, 756-781.

[45]. Suzić, N. (1981). Individualizacija nastave hemije poluprogramiranim radom sa udžbenikom i nastavnim filmom [Individualization of chemistry teaching semi-programmed with a textbook and a teaching film]. Pedagoška stvarnost br. 7, str. 609-620.

[46]. Сузић, Н. (1995). Особине наставника и однос ученика према настави [Teacher features and student attitudes toward teaching]. Бања Лука: Народна и универзитетска библиотека "Петар Кочић".

[47]. Сузић, Н. (1999). Интеракција као вид учења и поучавања [Interaction as a form of learning and teaching]. У зборнику [In Proceeding book (Н. Сузић, editor)] Интерактивно учење [Interactive learning] (pp. 9-44). Бања Лука, БиХ: Министарство просвјете и УНИЦЕФ.

[48]. Сузић, Н. (2001). Атрибуција циљева студената [Attribution of student goals]. Bacnuтање и образовање часопис за педагошку теорију и праксу, бр. 4/2001, стр. 51-69.

[49]. Suzić, N. (2005). Animiranje studenata u univerzitetskoj nastavi [Animating students in university teaching]. Banja Luka, BiH: Apeiron, Fakultet poslovne ekonomije.

[50]. Suzić, N. (2006). Ciljne orijentacije u ponašanju učenika [Target orientation in student behavior]. Pedagoška stvarnost br.7-8, 525-544.

[51]. Suzić, N. (2009). Kako učenici vrednuju školu i kako uče [How students value school and how they learn]. U zborniku [In Proceeding book]: Monografija međunarodnog znanstvenog skupa "Škola po mjeri" [Monograph of the International Scientific Meeting "School By Measure"] (pp. 221-236). Pula: Sveučilište Jurja Dobrile u Puli.

[52]. Сузић, Н. (2012). Футурологија у педагогији и социјалним наукама [Futurology in pedagogy and social sciences]. Бања Лука, БиХ: ЕКТОС.

[53]. Suzić, N. (2017). DENS - Dosljednost evaluacije nastave. Tekst u pripremi za objavljivanje [COTE - Consistency of teaching evaluation. Text in preparation for publication].

[54]. Ulug, M., Ozden, M. S., \& Eryilmaz, A. (2011). The effects of teachers' attitudes on students' personality and performance. Procedia: Social and Behavioral Sciences, 30,738-742.

[55]. UNESCO (2000). The progress of nations 2000. Na sajtu http://unicef.org/pon00. Očitano: 07.12.2010.

[56]. van Ryzin, M. J., Gravely, A. A., \& Roseth, C. J. (2009). Autonomy, belongingness, and engagement in school as contributors to adolescent psychological well-being. Journal of Youth and Adolescence, 38, 1-12. doi: 10.1007/s10964-007-9257-4

[57]. Wentzel, K. R. (1994). Social competence at school: Relation between social responsibility and academic achievement. Review of Educational Psychology, 86, 173-182.

[58]. Yager, R. E., \& McCormack, A. J. (1989). Assessing teaching/learning successes in multiple domains of science and science education. Science Education, 73(1), 45-58. 